\title{
Получение двумерных нанокристаллов Ві2Тез методом жидкофазной эксфолиации для использования в датчиках ИК диапазона спектра
}

\author{
Н.А. Лаврентьев ${ }^{1,2}$, Е.В. Мирофянченко ${ }^{1}$, А.Е. Мирофянченко ${ }^{1}$, В.С. Попов ${ }^{1,2}$ \\ ${ }^{1}$ Государственный научный иентр РФ АО «НПО «Орион», Москва, 111538,. Косинская, 9 \\ ${ }^{2}$ Московский физико-технический институт (национальный исследовательский университет), \\ 141701, Долгопрудный, Институтский пер., 9. \\ тел: +7 (499) 373-5310, факс:+7 (499) 373-68-62, эл.nочта: orion@orion-ir.ru
}

DOI 10.34077/RCSP2021-80

В последнее время активно развиваются методы получения графена и родственных двумерных углеродных материалов, обеспечивающих широкополосный фотоотклик. Однако сейчас такие материалы имеют низкую чувствительность и низкий коэффициент усиления проводимости, вызванный бесщелевой природой [1]. В последнее время особое внимание благодаря своим уникальным характеристикам привлекают материалы со свойствами топологических изоляторов [1-3]. Теллурид висмута ( $\left.\mathrm{Bi}_{2} \mathrm{Te}_{3}\right)$ является характерным представителем материалов этого вида [3].

Метод жидкофазной эксфолиации, позволяет воспроизводимо получать двумерные нанокристаллы теллурида висмута чувствительные к излучению ИК диапазона [4].

Исследование процесса получения двумерных нанокристаллов $\mathrm{Bi}_{2} \mathrm{Te}_{3}$ с заданными спектральными параметрами является важной и актуальной задачей.

В работе, из объёмного кристаллического теллурида висмута, методом жидкостной эксфолиации формировали суспензии нанокристаллов, как в различных дисперсионных средах, так и при различных режимах ультразвуковой обработки. Различными аналитическими методами были измерены средние толщины и латеральные размеры частиц. Кроме этого, полученные рамановские спектры и данные рентгеновской дифрактометрии, показывают различия в строении кристаллической решётки полученных нанокристаллов и объемного материала. Кроме этого, были обнаружены зависимости спектральных характеристик от размера кристаллов.

Методом drop-casting были сформированы тестовые фоторезистивные структуры. Для них были измерены вольтамперные характеристики в темновом режиме, а также ВАХ, полученные при засветке образцов источником излучения ближнего и среднего ИК диапазона. Характер поведения ВАХ может говорить о наличии фоточувствительности в ИК диапазоне спектра.

Спектры полного внутреннего отражения (ATR) и спектры пропускания плёнок, полученных методом dip-coating, подтверждают возможность направленного изменения спектральных характеристик, вызванных изменением ширины запрещённой зоны.

Таким образом, показано влияние режимов ультразвуковой обработки на спектральные характеристики синтезируемого материала, что даёт возможность направленного получения материалов с заданными спектральными свойствами для перспективных устройств ИК фотосенсорики.

Исследование выполнено при частичной финансовой поддержке РФФИ в рамках научного проекта № 18-29-20080 и Фонда содействия инновациям в рамках договора № 16551ГУ/2021.

\section{Литература}

[1] Пономаренко В. П., Попов В. С., Попов С. В., Чепурнов Е. Л. Фото- и наноэлектроника на основе двумерных 2D-материалов (Часть I. 2D-материалы: свойства и синтез) // Успехи прикладной физики. 2019. Т. 7. № 1. С. 10.

[2] B. Wang, S. Zhong, P. Xu, H. Zhang Recent development and advances in Photodetectors based on twodimensional topological insulators J. Mater. Chem. C, 2020, 8, 15526

[3] Пономаренко В. П., Попов В. С., Попов С. В. Фото- и наноэлектроника на основе двумерных 2Dматериалов (Часть II. 2D-нанотранзисторы) // Успехи прикладной физики. 2020. Т. 8. № 1. С. 33.

[4] Попов, В.С., Егоров, А.В., Пономаренко, В.П. Получение фоточувствительных элементов на основе двумерного теллурида висмута и их вольт-амперные характеристики // Прикладная физика 2020 №5 C.50. 